\title{
AKTUALNE DEJAVNOSTI NA PODROČJU MEDGENERACIJSKEGA SODELOVANIA V SLOVENIJI
}

\section{POVZETEK}

Članek obravnava dejavnosti, ki trenutno potekajo na področju medgeneracijskega sodelovanja v Sloveniji. V prvem delu članka avtorica pojasni nekatere pojme v zvezi z obravnavano temo in njihovo uporabo $v$ članku. V nadaljevanju na kratko povzame spremembe, ki se zaradi spremenjenih demografskih značilnosti pojavljajo pri nas in drugod po svetu na področju medgeneracijskega sodelovanja, ter razloži nov pomen, ki ga medgeneracijsko sodelovanje dobiva v sodobnem času. $V$ zadnjem delu članka povzame dejavnosti nekaterih akterjev, od vladnih resorjev do nevladnih organizacij ter dejavnih posameznikov na omenjenem področju v Sloveniji. Cilj članka je pregled in povzetek trenutnih dejavnosti na področju medgeneracijskega sodelovanja $v$ Sloveniji z namenom osvetlitve nekaterih težav, spodbujanja novih raziskav in vzpostavitve bolj sistematičnega povezovanja akterjev.

Ključne besede: medgeneracijsko sodelovanje, Slovenija

\section{CURRENT ACTIVITIES IN THE FIELD OF INTERGENERATIONAL COOPERATION IN SLOVENIA - ABSTRACT}

The article discusses activities, taking place in the field of intergenerational cooperation in Slovenia at the present time. In the first part the author explains certain terms related to the subject discussed and their use in the article. Next she sums up the changes in the field of intergenerational cooperation caused by demographic changes, which have appeared both in this country and abroad. She then explains the new significance of intergenerational cooperation in the present-day world. In the last part of the article she sums up the activities undertaken by some of the participants, ranging from governmental institutions to non-governmental organizations and individuals, active in the field of intergenerational cooperation in Slovenia. The main aim of the article is to review and summarize recent activities in the field of intergenerational cooperation in Slovenia in order to highlight certain difficulties, to stimulate new research and to establish more systematic connections between participants..

Keywords: intergenerational cooperation, Slovenia

\section{UVOD}

Z zniževanjem stopnje rodnosti in podaljševanjem življenjske dobe se v evropskih družbah klasična medgeneracijska razmerja hitro spreminjajo, kar od oblikovalcev politik na vseh ravneh zahteva, da jih opredelijo na novo. Ker $\mathrm{v}$ tem trenutku množice otrok blaginje, rojenih med letoma 1945 in 1965, dosegajo upokojitveno starost, smo prišli do prelomne točke demografskega razvoja. Omenjene značilnosti veljajo tudi za Slovenijo, ki sodi v krog dežel s starejšim prebivalstvom. Ob popisu prebivalstva v Sloveniji leta 1991 je znašal delež starejših od 65 let v celotnem prebivalstvu 11,2 odstotka, ob popisu leta 2002 se je povečal že na 14,7 odstotka, ob koncu leta 2005 pa je bilo pri nas že več kot 15,5 odstotka starejših od 65 let, kar drugače povedano pomeni, da je $\mathrm{v}$ tej starostni dobi že več kot 310 tisoč prebivalcev Slovenije (Strategija varstva starejših do leta 2010, 2002: 41).

Demografske spremembe so nas prisilile, da smo na različnih ravneh začeli razmišljati o potrebi po solidarnosti med generacijami, zato medgeneracijsko sodelovanje pridobiva vedno večjo pozornost države, civilne družbe in strokovnjakov. 


\section{KAJ JE MEDGENERACIJSKO SODELOVANJE?}

V članku se bomo držali razdelitve življenjske dobe človeka na tri obdobja oz. generacije. Za generacijo bomo šteli ljudi približno enake starosti, ki živijo v istem času in imajo podobne interese ali nazore. Prvo življenjsko obdobje obsega otroštvo, čas šolanja in usposabljanja, značilna zanj je odvisnost od odraslih (Krajnc, 1992: 11). Vsem pripadnikom tega življenjskega obdobja bomo rekli prva oz. mlada generacija. Drugo življenjsko obdobje se začne s povprečnim časom zaposlitve in poklicnim delom, konča pa z upokojitvijo. Vstopni značilnosti za srednjo generacijo sta tudi začetek samostojnega gospodinjstva in rojstvo prvega otroka (Strategija varstva starejših do leta 2010, 2002: 45). Drugo življenjsko obdobje zaznamujeta še izbira partnerja in poroka. Pripadnike tega življenjskega obdobja bomo imenovali druga oz. srednja generacija. Za tretje življenjsko obdobje so značilne upokojitev, zamenjava okolja, nove navade, osamljenost, ovdovelost, izguba prejšnjega socialnega statusa (Krajnc, 1992: 11). Pripadnike tega življenjskega obdobja bomo imenovali tretja oz. stara generacija. Pri načrtovanju različnih medgeneracijskih programov lahko generacije še podrobneje razdelimo, npr. prvo generacijo na otroke in mladostnike, drugo generacijo na mlajše in starejše odrasle, tretjo generacijo pa na mlajše (do 65. leta starosti) in starejše starostnike (razdelitev starostnikov v Salobir, 2004, v Gamse, 2008). Pripadnike generacij v posameznih zgodovinskih obdobjih zaznamujejo tudi nekatere skupne vrednote, norme, navade in tudi nekateri stereotipi o njih. V strokovni literaturi navadno poimenujejo z oznako »medgeneracijski programi « tiste programe, kjer se družita dve ali več generacij, ki niso stične (otroci in mlajši starejši, mlajši odrasli in ljudje v pozni starosti) (Ličen, 2009: 64). Medgeneracijski programi bi lahko imenovali tudi tiste, v katerih sodelujejo stične generacije. Srednja generacija ima zaradi odvisnosti mlajše in izključenosti starejše generacije velikokrat vlogo organizatorja in povezovalca, čeprav v samih dejavnostih programov včasih ne sodeluje. Srednja generacija je tudi pomemben načrtovalec takih programov. Programi medgeneracijskega sodelovanja so si glede načina vključevanja generacij zelo različni. Za medgeneracijske programe bomo torej označili vse tiste načrtovane programe, $v$ katerih sodelujeta vsaj dve generaciji in $\mathrm{v}$ obliki neformalnega učenja oz. druženja izmenjujeta znanje in izkušnje ter bogatita lastno socialno mrežo in socialno mrežo preostalih akterjev.

Medgeneracijsko sodelovanje zajema vse programe oz. dejavnosti, ki se v državi izvajajo na tem področju. Sodelovanje poteka skozi dialog, ki pa se odvija s pomočjo različnih metod (npr. druženje, učenje, ekonomska podpora). Vse te metode pripomorejo $\mathrm{k}$ večanju medgeneracij-

\section{Skica 1: Medgeneracijsko sodelovanje (avtorska skica)}

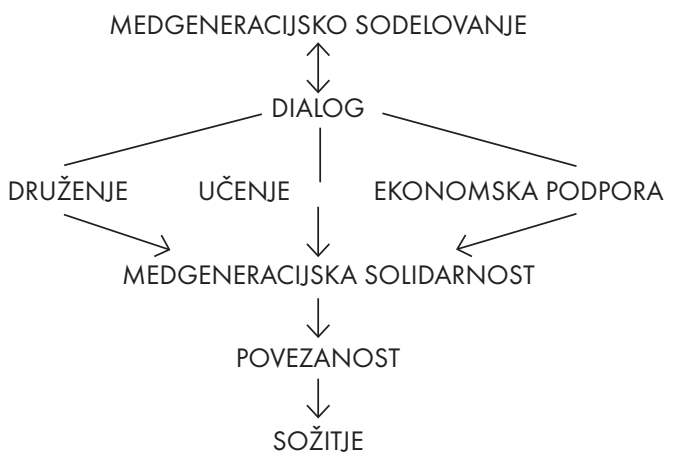


ske solidarnosti in povezanosti, njihov rezultat pa je sožitje med generacijami (glej Skico 1).

\section{SPREMEMBE V POMENU IN OBLIKAH MEDGENERACIJSKEGA SODELOVANIA NEKOČ IN DANES}

Za preteklost je bilo značilno neformalno medgeneracijsko sodelovanje, predvsem znotraj družine. Medgeneracijsko učenje v družinah je stoletja pomenilo neformalni ali priložnostni način za prenos znanja, veščin, kompetenc, norm in vrednot med generacijami (Kump, 2008). Hiter tehnološki razvoj, industrializacija in družbene spremembe v prejšnjem stoletju pa so v medgeneracijske odnose prinesli številne premike. Zaradi hitrih sprememb je starejša generacija izgubljala kompetentnost na področju priprav mlajše generacije na vstop v samostojno življenje, poleg tega sta se vzgoja in izobraževanje vedno bolj formalizirala in profesionalizirala. Generacije so v zadnjem stoletju dosegle izjemen razvoj znanja na materialno-tehničnem in naravoslovnem področju, medtem ko so znanje in možnosti za kakovost osebnostnega razvoja in medčloveškega sožitja zelo zaostali - prav to dvoje pa je odločilnega pomena za kakovostno staranje in solidarno sožitje med generacijami. Treba bi bilo zmanjšati odvisnost družbenega položaja od zaposlitve (Findeisen, 2005) ter že v procesu zgodnje vzgoje in izobraževanja poudarjati starost kot obdobje prenašanja spoznanj in izkušenj.

Možnosti za družinsko in domačo oskrbo starih ljudi se danes krčijo. Tudi za družinsko

Konflikti med generacijami so stari toliko kot civilizacija sama. Na štiri tisoč let stari glineni ploščici so našli zapisano: Današnja mladina je nemogoča. Ne pozna nobene odgovornosti in spoštovanja, po glavi pa ji rojijo same neumnosti (Ujčič, 2002). So pa razmerja med generacijami in konflikti med njimi privzeli nekatere značilnosti družbenozgodovinske dobe. oz. sorodstveno socialno mrežo velja, da se v njej hitro veča delež starih ljudi, delež mlade in srednje generacije pa upada. Veča se tudi delež starih ljudi, ki živijo sami ali skupaj z drugim starim človekom. Države in stroke so pred izzivom, kako hitro razviti in razširiti nove modele pomoči družini s starim človekom, nove človeku prijazne programe oskrbe starih ljudi in druge podporne socialne mreže za kakovostno staranje in sožitje generacij v krajevni skupnosti. V okviru EU se hitro uveljavljajo taki programi za oskrbo starih ljudi, ki so vezni člen med družino in institucionalnim varstvom. Takšni so zlasti dnevno varstvo, oskrMedgeneracijsko
sodelovanje
je sožitje med
generacijami. bovana stanovanja, socialna oskrba in nega na domu, začasno varstvo za oddih svojcev ter medgeneracijsko prostovoljstvo, ki so sodobni programi za vzpostavljanje novega ravnotežja med odgovornostjo posameznika, njegove družine, države in civilne družbe na področju skrbi za kakovostno staranje in solidarno sožitje med generacijami (Strategija varstva starejših do leta 2010, 2002: 9).

Kakor sta se sčasoma socializacija in izobraževanje premaknila $\mathrm{v}$ institucionalno sfero, tako dandanes tudi medgeneracijsko sodelovanje vse bolj postaja predmet formalnega in organiziranega delovanja. Medgeneracijski stiki, ki so bili nekoč naravni del življenja v družini, postajajo vse bolj vsebina socialnih, humanitarnih programov vladnih in nevladnih organizacij. Ker je vprašanje sožitja in solidarnosti med generacijami eno od ključnih za našo prihodnost, ga ne moremo več prepuščati naključju.

\section{KAJ SE DOGAJA NA PODROČJU MEDGENERACIJSKEGA SODELOVANIA V SLOVENIJI?}

V Sloveniji medgeneracijsko sodelovanje še nima širokih razsežnosti kot npr. na Nizozemskem, v Veliki Britaniji, na Švedskem, 
Finskem ali v ZDA, kjer se programi medgeneracijskega sodelovanja izvajajo že od 70. let prejšnjega stoletja. Kljub temu pa se predvsem v zadnjem času vedno več organizacij ukvarja s krepitvijo sodelovanja generacij.

$\mathrm{V}$ tem poglavju bomo na kratko pregledali dogajanja na področju medgeneracijskega sodelovanja v Sloveniji v zadnjem času.

Leta 2007 je bila v Sloveniji napisana Strategija varstva starejših do leta 2010 - solidarnost, sožitje in kakovostno staranje prebivalstva. Avtorji strategije trdijo, da je to »odgovor Republike Slovenije na staranje prebivalstva in na evropske zahteve po skrbi za novo solidarnost med generacijami. Osnovni namen strategije je uskladiti in povezati delo pristojnih vladnih resorjev $\mathrm{z}$ gospodarstvom in civilnim tretjim sektorjem, tako da se povečata solidarnost in kakovost medčloveškega sožitja med tretjo, srednjo in mlado generacijo ter zagotovita kakovostno staranje in oskrba naglo rastočega deleža tretje generacije« (Strategija varstva starejših do leta 2010, 2002: 3).

Istega leta je bil na podlagi strategije ustanovljen Svet Vlade RS za solidarno sožitje generacij in za kakovostno staranje prebivalstva, katerega naloga je spremljanje uresničevanja ciljev strategije. Svet sestavljajo predstavniki vladnih resorjev, predstavniki izvajalcev storitev in programov za starejše, predstavniki znanstvenoraziskovalnega področja ter predstavniki civilne družbe.

Leta 2008 je bila na Brdu pri Kranju mednarodna konferenca Medgeneracijska solidarnost za družbe sožitja in socialne povezanosti, ki jo je med svojim predsedovanjem Svetu Evropske unije organizirala Slovenija v sodelovanju z Evropsko komisijo in več nevladnimi organizacijami. Namen konference je bil poudariti nujnost medgeneracijskega sodelovanja in solidarnosti kot ene najpomembnejših prvin $\mathrm{v}$ času vse izrazitejših demografskih sprememb. $\mathrm{Na}$ njej sta bila podana predlog za določitev 29. aprila kot evropskega dneva medgeneracijske solidarnosti in predlog za določitev leta
2012 kot evropskega leta aktivnega staranja. Že naslednje leto je bil 29. april prvič zaznamovan kot evropski dan medgeneracijske solidarnosti. V državah Evropske unije in drugod po svetu so bili organizirani številni dogodki s to temo. V Zvezi prijateljev mladine Slovenije in njenih članicah - društvih in zvezah - načela ustvarjalnega medgeneracijskega sodelovanja že več desetletij gojijo v množici programov. Ob sofinanciranju ministrstva za delo, družino in socialne zadeve denimo pripravljajo medgeneracijske tabore, kjer otroci in mladostniki nekaj dni živijo in se družijo s starimi ljudmi. Cilji teh druženj so: medsebojno spoznavanje in sodelovanje, izmenjava izkušenj in znanj, vzpostavitev podlage za nadaljnje sodelovanje, pridobitev novih znanj in sprostitev.

Tudi Slovenska filantropija ima na področju medgeneracijskega sodelovanja že nekajletne izkušnje. V njihovem okviru se izvaja projekt Sadeži družbe, namenjen ustvarjanju in krepitvi vezi med mladimi in starejšimi. Je projekt vzgoje za strpnost, solidarnost in medsebojno razumevanje. Temelji na prostovoljskem delu mladih za starejše, ki živijo doma, in starejših za mlade s povezovanjem šol in društev upokojencev. V projekt so vabljene tudi vse preostale organizacije, ki že izvajajo različne medgeneracijske dejavnosti. Sodelujejo lahko vse osnovne in srednje šole, mladinske in študentske organizacije, vsa društva upokojencev in druge prostovoljske organizacije, ki vključujejo starejše. Pridružijo se lahko starši in šole s spodbujanjem otrok k prostovoljskemu delu s starejšimi, starejši, ki živijo doma, lokalna društva upokojencev in drugi, ki želijo s prostovoljstvom soustvarjati boljšo družbo (http://www.prostovoljstvo.org/main. php?mod_id=80). Septembra 2009 je svoja vrata odprla Hiša Sadeži družbe v Murski Soboti. Projekt Hiša Sadeži družbe je nadgradnja že uveljavljenega projekta Sadeži družbe, ki ga od leta 2006 uspešno soustvarjata Slovenska filantropija in Zveza društev upokojencev Slovenije. Delavnice, ki se izvajajo v Hiši, daje- 
jo poudarek druženju, skupnemu ustvarjanju, promociji zdravega življenja in prostovoljstva. Načrtujejo pa tudi dejavnosti, ki bodo pripomogle k boljši socializaciji med mlajšo in starejšo generacijo: glasbeni nastopi, kuharske, čebelarske, fotografske, umetniške in druge mojstrske delavnice, gledališke igre, družabne igre na prostem, ekskurzije, povezane s športnimi in kulturnimi dogodki. Prvi medgeneracijski center v Sloveniji, Hiša Sadeži družbe, bi lahko postal model, ki bi ga uporabili tudi v drugih slovenskih mestih in krajih.

Zveza društev za socialno gerontologijo Slovenije ima pomembno vlogo $\mathrm{v}$ gojenju medgeneracijskega sodelovanja. Organizira medgeneracijske tabore, ki so podporni program skupinam za samopomoč. Skupine starih ljudi za samopomoč so skupine naključno zbranih posameznikov, ki se redno srečujejo z namenom postati prijateljska skupina. Ustanavljanje teh skupin je eden najobsežnejših projektov na področju zadovoljevanja nematerialnih potreb starih ljudi v Republiki Sloveniji in je edinstven v Evropi. Poteka od leta 1987. Ciljne skupine medgeneracijskih taborov so: člani skupin starih ljudi za samopomoč (predstavniki generacije starih ljudi), voditelji skupin, mentorji prostovoljskega dela (predstavniki srednje generacije), mladi, ki so že vključeni v kakšno organizirano obliko prostovoljskega dela s starimi ljudmi (predstavniki mlade generacije).

V Sloveniji deluje tudi veliko medgeneracijskih društev, ${ }^{1}$ vendar je njihovo delovanje malo raziskano. Na spletni strani Zveze društev za socialno gerontologijo lahko najdemo kratke opise njihovih zelo zanimivih dejavnosti.

Medgeneracijsko sodelovanje poudarjajo tudi

Cilji medgeneracijskih taborov so povezovanje predstavnikov vseh treh generacij, spreminjanje stališč in odprava tabujev o predstavnikih mlade in stare generacije, učenje in pretok življenjskih izkušenj, medsebojna pomoč in solidarnost. univerze za tretje življenjsko obdobje. V Sloveniji obstaja spletna stran za starejše www. seniorji.info, katere poslanstvo je posredovanje kakovostnih in uporabnih informacij za zadovoljno in polno življenje starejših. Spletna stran spodbuja medgeneracijsko povezanost in vseživljenjsko izobraževanje (http://www.seniorji.info/novica.php?ids=16\&id=135).

Eden od spodbujevalcev medgeneracijskega sodelovanja v Sloveniji je tudi Festival za tretje življenjsko obdobje, ki je letos že desetič zapovrstjo ponudil prostor za sodelovanje med generacijami, civilno družbo, prostovoljskimi organizacijami, gospodarsko, akademsko in politično sfero ter s tem poskusil pripomoči $\mathrm{k}$ oblikovanju trajnostnih medgeneracijskih rešitev. Cankarjev dom je med 29. septembrom in 1 . oktobrom odprl vrata medgene-

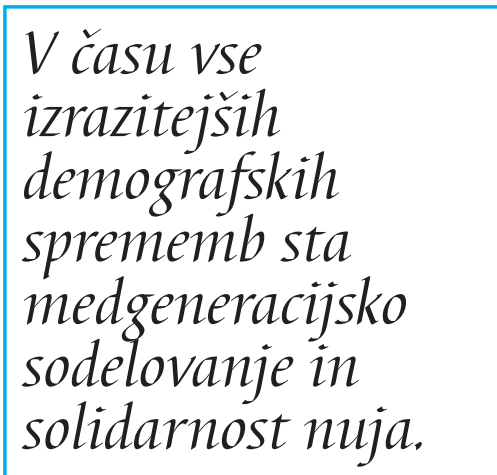
racijskemu sožitju, ustvarjalnosti in izmenjavi idej. Časovno in vsebinsko se festival navezuje na 1. oktober, ki je mednarodni dan starejših, in na 3. oktober, ki je mednarodni dan otroka, rdeča nit dogodka pa je bila letos evropsko leto boja proti revščini in socialni izključenosti.

$\mathrm{Z}$ vidika medgeneracijskega sodelovanja so pomembne tudi nekatere ljudske univerze po Sloveniji. Na Ljudski univerzi Ajdovščina se je v okviru Grundtvigovega projekta Tandems go! vzpostavila mreža povezav med osnovno šolo, ljudsko univerzo in univerzo. Predstavljala je okvir za projekt medgeneracijskega učenja, ki se razvija na ljudski univerzi (sodelovanje študentk in starejših) in osnovni šoli (sodelovanje učencev in starejših). Starejše želijo spodbuditi k učenju s pomočjo vključevanja v tandeme, kjer se učijo računalniških spretnosti in slednje uporabijo za zapisovanje zgodb iz lokalne kulture (Ličen, 2010).

Pomembne projekte na področju medgeneracijskega sožitja razvijajo na Inštitutu Antona Trstenjaka v Ljubljani. Največji in izvirni ak- 
cijsko-razvojni projekt inštituta je razvijanje socialne mreže za kakovostno staranje in sožitje med generacijami. Za to mrežo so doslej razvili več med seboj povezanih programov, ki se razvrščajo v štiri vsebinske sklope: informiranje in ozaveščanje skupnosti o kakovostnem staranju in sožitju generacij, projektno organizacijski programi za uvajanje medgeneracijske socialne mreže v skupnosti, usposabljanje za kakovostno staranje in sožitje med generacijami, prostovoljski programi in programi za vzpostavitev samoorganizacije in trajnega delovanja nove krajevne medgeneracijske socialne mreže za kakovostno staranje in sožitje med generacijami. Na podlagi raziskovanja in terenskega uvajanja socialne mreže za kakovostno staranje in sožitje med generacijami so na inštitutu dobili tudi zamisel za vzpostavljanje medgeneracijskih središč.

$\mathrm{V}$ medgeneracijsko sodelovanje se v Sloveniji vse bolj vključujejo tudi domovi za ostarele, osnovne in srednje šole ter društva upokojencev. V medijih (predvsem na spletnih straneh šol oz. domov za ostarele) je mogoče zaslediti veliko dokumentiranih medgeneracijskih dogodkov.

Letos so se ob 29. aprilu zvrstile številne prireditve $\mathrm{v}$ počastitev evropskega dneva medgeneracijske solidarnosti.

Svet Vlade RS za solidarno sožitje generacij in za kakovostno staranje prebivalstva v Sloveniji je organiziral sejo in tako zaznamoval 29. april kot evropski dan medgeneracijske solidarnosti. Seja je bila namenjena predstavitvi primerov dobrih praks $\mathrm{v}$ različnih projektih medgenera- cijskega sodelovanja ter pogledov in predlogov za spodbujanje medgeneracijskega sodelovanja in medgeneracijske solidarnosti $\mathrm{v}$ prihodnosti. Programski odbor Festivala za tretje življenjsko obdobje, ki v Sloveniji poteka vsako jesen, je z namenom združiti dosedanje izkušnje in spoznanja ter dodatno pripomoči h gradnji medgeneracijsko strpne, solidarne in vsem generacijam prijazne slovenske družbe organiziral srečanje za ustanovitev Gibanja za medgeneracijsko sodelovanje. Na področju medgeneracijskega sodelovanja deluje v Sloveniji veliko vladnih in nevladnih organizacij ter posameznikov, njihova prizadevanja in delovanje pa pogosto ostajajo neopažena. Organizatorji so prepričani, da bi povezovanje vseh akterjev, ki na različne načine krepijo medgeneracijsko sodelovanje v Sloveniji, lahko prineslo nov kakovosten premik na tem področju, predvsem pa pomagalo ozaveščati ljudi. Ustanovitev Gibanja za medgeneracijsko sodelovanje se kaže kot logično nadaljevanje dosedanjih dejavnosti. Pridružijo se mu lahko vse institucije, organizacije in posamezniki, ki delujejo na tem področju. Namen posveta je bil poleg ustanovitve omenjenega gibanja tudi sprejetje Listine o gibanju za medgeneracijsko sodelovanje v Sloveniji. Listina naj bi bila tisti temelj, na katerem bi se $\mathrm{v}$ prihodnje povezovali vsi dejavniki na področju medgeneracijskega sodelovanja. Skupaj bi tvorili gibanje, ki bi spodbujalo medgeneracijsko sožitje in solidarnost, ki morata postati ena najpomembnejših vrednot družbe jutrišnjega dne. Na srečanju je bil v ospredje postavljen

Krajevno medgeneracijsko središče je kompleksen model skupnostnega menedžmenta za sinergično povezavo vseh političnih, civilnih in drugih programov, služb, organizacij in drugih subjektov, ki so v skupnosti potrebni za oskrbovanje dveh vitalnih področij sožitja: za kakovostno staranje in za solidarno sožitje med mlado, srednjo in tretjo generacijo v zdajšnjih razmerah, ko ne zadostujejo več tradicionalni vzorci sožitja in se hitro veča delež starega prebivalstva. Temelj modela krajevnega medgeneracijskega središča je celostna antropologija: holistično gledanje na človeka v njegovi telesni, duševni, socialni, duhovno-eksistencialni in razvojni razsežnosti, neločljivo dopolnjevanje telesnega, duševnega in socialnega zdravja, komplementarna povezanost vseh treh generacij ter življenjsko ravnotežje med posameznikom in skupnostjo (http://www.inst-antonatrstenjaka.si/ medgeneracijskasredisca.html). 
pomen družine, kjer se mora začeti vzgoja za medgeneracijsko solidarnost. Navzoči so se strinjali z vsebino listine, slišati pa je bilo tudi nekaj kritik, npr. o pomanjkljivih temeljih oz. pomanjkljivo izoblikovanih vrednotah, na katerih naj listina temelji, in premalo konkretno zastavljenih ciljih. O ustanovitvi Gibanja za medgeneracijsko sodelovanje je bilo na srečanju malo govora, prav tako o težavah, s katerimi se srečujejo akterji na področju medgeneracijskega sodelovanja. V ospredju je bila potreba po oblikovanju ustrezne terminologije.

Inštitut Antona Trstenjaka za gerontologijo in medgeneracijsko sožitje je ob drugem evropskem dnevu medgeneracijske solidarnosti organiziral praznični posvet. Osrednja vsebinska točka je bila okrogla miza o medgeneracijski solidarnosti v Sloveniji, vzgoji zanjo in njenem uresničevanju pri dolgotrajni oskrbi, kjer so se dotaknili tudi sprejemanja zakona o dolgotrajni oskrbi in solidarnem zavarovanju zanjo v Sloveniji.

\section{ZAKLJUČEK}

Slovenija je pred izzivom, kako v trenutnih demografskih razmerah ohraniti in izboljšati sisteme medgeneracijske solidarnosti ter vzpostavi ustrezne povezave med različnimi vladnimi resorji in nevladnimi organizacijami ter dejavnimi posamezniki. To pa ni preprosta naloga, saj se načrtovanje medgeneracijskih programov dotika družine, vzgoje in izobraževanja, zaposlovanja, dela, pokojninskega zavarovanja, stanovanjske politike, zdravstva, prostorskega načrtovanja itd. V tem kontekstu so potrebni skrbno in dolgotrajno načrtovanje, vključevanje različnih strok in vzpostavitev ustreznega sistema vzdrževanja in razvoja medgeneracijskega sodelovanja. V Sloveniji je treba konkretneje opredeliti naloge različnih akterjev, ki sodelujejo $\mathrm{v}$ negovanju medgeneracijskega sožitja, prav tako je treba eksplicitno določiti telo, ki bi delovalo kot povezovalec vseh teh programov. Hans Peter Winter, strokovnjak za bivalna okolja in programe dolgotrajne oskrbe, je v enem od svojih intervjujev o Sloveniji povedal, da je med najprodornejšimi $v$ Evropi po znanju na tem področju, vendar ji idej ne uspe uresničiti v praksi (http://www.inst-antonatrstenjaka.si/clanek.asp?ID=185). Podobno je tudi v preostali Evropi. Empirična analiza ekonomskih, socialnih in okoljskih razvojnih značilnosti evropskih držav razkriva, da sedanji razvojni trendi niso trajnostni in se oddaljujejo od zastavljenih strateških ciljev. V tem kontekstu so pomembne predvsem prihodnje naloge $\mathrm{z}$ vidika medregionalne in medgeneracijske pravičnosti in odgovornosti (Vintar Mally, 2007).

Zaključimo lahko, da si je Slo-
Vzgoja za medge- neracijsko solidar- nost se mora začeti $v$ družini. venija glede razvoja medgeneracijske solidarnosti že zastavila cilje, ki so skladni s trenutnimi potrebami in dogajanji v družbi, ter da so $\mathrm{v}$ zadnjih letih vidni nekateri premiki. Medgeneracijsko sodelovanje je postalo aktualna tema $\mathrm{v}$ raznih strokah, akademskih razpravah in raziskavah. Večjo pozornost pa je treba usmeriti v uresničevanje zastavljenih ciljev, izvesti manjkajoče raziskave praktičnega pomena ter ideje in konkretne programe medgeneracijske solidarnosti intenzivneje prenesti v politiko na lokalni ravni, vključiti pa je treba tako središče kot obrobja države in upoštevati tudi posebne potrebe podeželskega prebivalstva.

\section{LITERATURA IN VIRI}

Findeisen, D. (2005). Prihodnost starejših v Evropi. Ljubljana: Prispevek na VIII. mednarodnem kongresu EURAG. Dostopno prek: http://www. univerzazatretjeobd-drustvo.si/strokovniclanki.htm. Javornik S., J. (ur.) (2006). Socialni razgledi 2006. Ljubljana: Urad RS za makroekonomske analize in razvoj.

Javrh, P. (2009). Medgeneracijsko učenje v najžlahtnejšem smislu. Medgeneracijsko sožitje kot prvina vseživljenjskega učenja. Ljubljana: Andragoško društvo Slovenije. 
Jelenc, Z. (2009). Vseživljenjsko učenje - za zdaj promoviranje bolj kot sistemsko urejanje. Medgeneracijsko sožitje kot prvina vseživljenjskega učenja. Ljubljana: Andragoško društvo Slovenije.

Jelenc Krašovec, S. (2009). Starejši ljudje med delom in prostim časom. Medgeneracijsko sožitje kot prvina vseživljenjskega učenja. Ljubljana: Andragoško društvo Slovenije.

Krajnc, A. (1992). Kako smo snovali Slovensko univerzo za tretje življenjsko obdobje. Ljubljana: Univerza za tretje življenjsko obdobje.

Kump, S. (2008). »Nova paradigma medgeneracijskega učenja«. Andragoška spoznanja, 3/4: 62-74.

Kump, S., Jelenc Krašovec, S. (2005). »Izobraževanje - možni dejavnik krepitve moči in vpliva starejših odraslih«. Družboslovne razprave, 49/50: 243-261.

Kump, S., Jelenc Krašovec, S. (2010). Medgeneracijsko sožitje in učenje. Pedagoško-andragoški dnevi 2010: Kulture v dialogu. Ljubljana: Znanstvena založba Filozofske fakultete Univerze v Ljubljani.

Kuhar, M. (2007). Sociološki vidik: prevrednotenje staranja in starosti. Odnos Slovencev do starosti, pokojninskega sistema in varčevanja za starost: Zbornik ob 10. obletnici Kapitalske družbe. Ljubljana: Kapitalska družba.

Ličen, N. (2009). Uvod v izobraževanje odraslih. Ljubljana: Znanstvena založba Filozofske fakultete Univerze v Ljubljani.

Ličen, N. (2009). Medgeneracijsko učenje v lokalni skupnosti - študija primera. Medgeneracijsko sožitje kot prvina vseživljenjskega učenja. Ljubljana: Andragoško društvo Slovenije.

Ličen, N. (2010). Zgodbe o aleksandrinkah - primer medgeneracijskega in medkulturnega učenja. Pedagoško-andragoški dnevi 2010: Kulture v dialogu. Ljubljana: Znanstvena založba Filozofske fakultete Univerze v Ljubljani.

Strategija varstva starejših do leta 2010 - Solidarnost, sožitje in kakovostno staranje prebivalstva (2002). Ljubljana: Ministrstvo za delo, družino in socialne zadeve, Vlada RS.

Vintar Mally, V. (2007). »Trajnostni izzivi Evrope v 21. stoletju«. Dela, 28: 239-253.

Zver Š., M. (ur.) (2002). Sožitje generacij, Zbornik referatov z okrogle mize. Ilirska Bistrica: Dom starejših občanov.

http://www.predsedovanje.si/Medgeneracijsko-sodelovanje-/Medgeneracijski-dialog-in-izobra\%C5\%BEevanje-za-razvoj.html http://hisa.sadezidruzbe.org/index.php?id=7\&lang=sl http://www.umar.gov.si/fileadmin/user_upload/publikacije/socrazgledi/SR2006.pdf http://www.mladina.si/tednik/200709/clanek/slo--zaposlovanje-vanja_pirc-2/

http://www.skupine.si/medgeneracijska_drustva/ http://books.google.si/books?id=Ih3qMi-iRKcC\&pg $=$ PA228\&lpg=PA228\&dq=Kaplan, + M.+\%281990 $\% 29 .+\% 22$ Designing+Community+Participation+ Special+Events+that+Cross+Generational+Bound aries \&source $=$ bl\&ots $=0$ GZdEUJk9Y \&sig $=\mathrm{iGnt} 1 \mathrm{o}$ qgd9Wb3-gUT1Ee0i7cdoQ\&hl=sl\&ei=UanYS6W oH8TI-QaIp8iCBg\&sa=X\&oi=book_result \&ct=re sult\&resnum $=1 \&$ ved=0CAYQ6AEwAA\#v=onepa ge\&q=Kaplan $\% 2$ C\%20M.\%20\%281990\%29.\%20 $\% 22$ Designing\%20Community\%20Participation $\% 20$ Special $\% 20$ Events $\% 20$ that $\% 20$ Cross $\% 20$ Generational $\% 20$ Boundaries $\& \mathrm{f}=$ false

http://books.google.si/books?id=KZ4JUIvosiYC\& printsec $=$ frontcover $\&$ dq $=$ Kaplan,+ M. $+\% 28199$ $0 \% 29 .+\% 22$ Designing+Community+Participat ion+Special+Events+that+Cross + Generational + Boundaries\&source $=$ gbs_similarbooks_s\&cad $=1$ $\# \mathrm{v}=$ onepage $\& \mathrm{q} \& \mathrm{f}=$ false

http://books.google.si/books?id=u3AxBXTTw0kC $\&$ printsec $=$ frontcover $\& d q=$ Kaplan, + M. $+\% 2819$ $90 \% 29 .+\% 22$ Designing+Community+Participa tion + Special+Events + that+Cross + Generational + Boundaries\&source $=$ gbs_similarbooks_s\&cad $=1$ $\# \mathrm{v}=$ onepage \&q\&f=false

http://books.google.si/books?id=Q9YU0FPEWb4 $\mathrm{C} \&$ printsec $=$ frontcover $\& \mathrm{dq}=$ Kaplan,$+\mathrm{M} .+\% 281$ $990 \% 29 .+\% 22$ Designing+Community+Particip ation+Special+Events+that+Cross+Generational + Boundaries\&source $=$ gbs_similarbooks_s\&cad $=1$ $\# \mathrm{v}=$ onepage \&q\&f=false

http://www.inst-antonatrstenjaka.si

1 Društvo za samopomoč Jutro, Gornja Radgona, MD Lučka, Ravne na Koroškem, Društvo Most, Žalec, MD Žarek, Novo mesto, MD Zimzelen, Cerknica, MD Čebelica, Radovljica, MD za samopomoč Drava, Maribor, MD Jesen, Ilirska Bistrica, MD Mavrica, Poljčane, MD Svetilnik, Koper, MD za samopomoč Naše vezi, Nova Gorica, MD Jesenski cvet, Domžale, $M D$ za samopomoč Oljka, Polzela, MD 4 letni časi, Ajdovščina, MD za samopomoč Savinja, Celje, MD Z roko v roki, Kranj, MD Korak, Idrija, MD Vesela jesen, Trebnje. 